\title{
Impact of Teaching Materials using Adobe Flash to Enhance the Comprehension of Algorithms and Programming Course
}

\author{
H. Vidyaningtyas, L. V. Yovita, R. Mayasari \\ Telecommunication Engineering \\ Universitas Telkom \\ Bandung, Indonesia \\ huriantividya@telkomuniversity.ac.id
}

\author{
B. Hudiono, Y. Jamiah \\ Mathematics Education, \\ Universitas Tanjungpura, \\ Pontianak, Indonesia
}

\begin{abstract}
The goal of this study is to see the effect of the use of interactive media on Algorithms and Programming course. Based on preliminary studies, the causes of sub-optimal student learning outcomes are the inadequate both of teaching material and media that are used in the learning. Related to these findings, it is necessary to do a development of teaching materials with interactive media on Algorithms and Programming to support the learning in order to optimize both conceptual understanding and ability of programming language implementation. The method used is preliminary studies, design, development, and analysis. The population in this study is a first year student of School of Electrical Engineering Telkom University, with a total sample of 30 people. Testing is done by giving the pretest and posttest to the entire sample, which is the pretest is given to students by using teaching materials in the form of powerpoint while the post-test was given to students after trying teaching materials coupled with interactive media. The obtained average value of posttest for each chapter is $94,17 \%$ for the Sorting Chapter and 96,67\% for the Searching Chapter.
\end{abstract}

\section{INTRODUCTION}

Algorithms and Programming is one of the compulsory subjects in the School of Electrical Engineering, Telkom University. This course is given at first year of their study. Students felt that this course is difficult to understand. From the initial survey there are several problems related to the this course:

1. Majority of students was graduated from high school, they never learned Algorithm and Programming before.

2. The Lecturer have to teach a heavy lesson, but limited time.

3. The previous teaching methods are less effective.

From the result of the initial survey, our team decide to improve the delivery of Algorithm and programming material using animation with Adobe Flash. We choose Sorting and Searching chapter, because these material is the most difficult to teach. The animation help students to understand quickly.

For evaluation we used 2 methods that is: questionnaire and pre-test post-test. This evaluation given to 30 students as a sample. From the questionnaire, the students give the MOS more than 4 , for sorting and searching animation. It is mean that the animation is good and help them to understand the whole material. From the pre-test post-test, the student have an increasing average value significantly.

Based on the result, it is concluded that interactive media help students to understand the material. Bariers in understanding the material can be solved by making analogies or visualizations of related material in animation.incorporating the applicable criteria that follow.

\section{Method AND RESEARCH MODEL}

This research is included in the development research since the main objective is the development of innovative teaching and learning model, followed by the development of learning tools as the completeness of the application in a class that consists of three main stages, they are (1) the development of the relevant learning courses, (2) the development of learning model such as interactive media creation in an interactive slideshow program form, and (3) implementation or testing in the lecture.

The research model used in this study is the development method of Brog \& Gall (1989) that has been modified. The design consists of four steps : (1) preliminary study, (2) program planning, (3) program development, and (4) program validation. Furthermore, these are the research stages in detail :

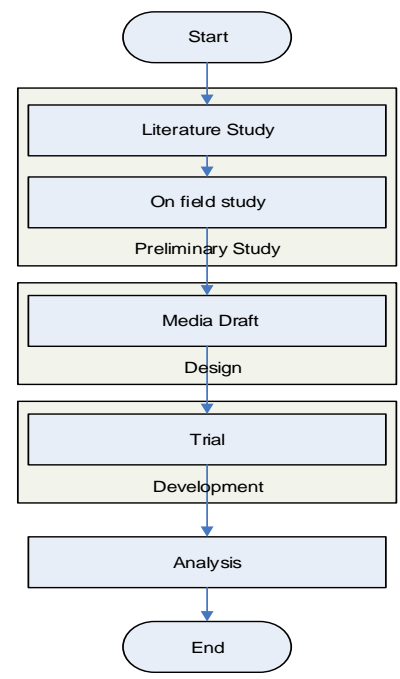

Fig. 1. Method Flowchart 


\section{RESULT}

\section{A. Interactive media}

Based on initial survey, our team designed and created interactive media using Adobe Flash in animation for two chapter about array, Sorting and Searching chapter. These material is the most difficult to teach if we use the previous teaching methods. The following are captured images of one of media that had been made:

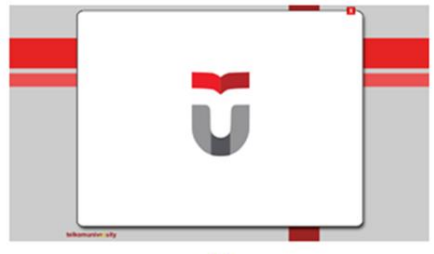

(a)

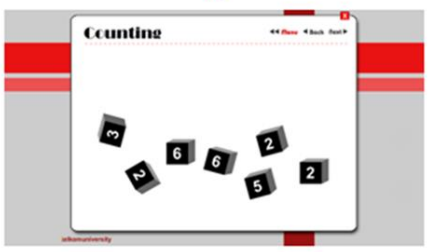

(c)



(b)

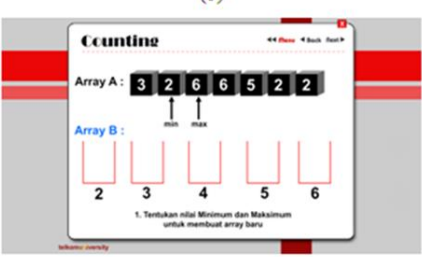

(d)
Fig. 2. (a) (b) (c) (d) Capture from Sorting animation

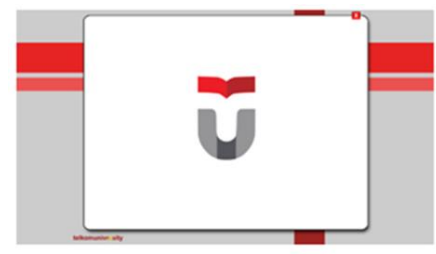

(a)

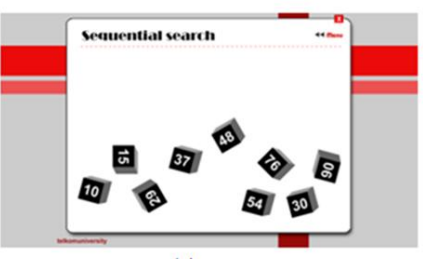



(b)

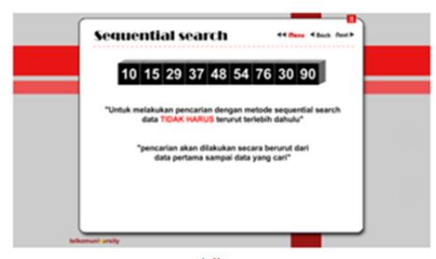

Fig. 3. (a) (b) (c) (d) Capture from Searching animation

\section{B. Evaluation}

The evaluation methods consist of : questionnaire and pretest post test. The questionnaire aims to determine the subjective opinion generated by collecting the opinion of students who have tried the application that has been made. Pre-test post test aims to determine the students level of understanding of the material, before and after using animation in the learning process. The sampled students were 30 person.

Questionnaire consist of the following question

\begin{tabular}{|l|l|}
\hline \multicolumn{1}{|c|}{ Sorting Questionnaire } & \multicolumn{1}{|c|}{ Searching Questionnaire } \\
\hline $\begin{array}{l}\text { 1. Have you ever taken } \\
\text { algorithms and programming } \\
\text { course? }\end{array}$ & $\begin{array}{l}\text { 1. Have you ever taken } \\
\text { algorithms and programming course } \\
?\end{array}$ \\
\hline
\end{tabular}

2. Determine scale level of ease of use application of interactive animations.

3. How helpful is this interactive animation for you to understand the Counting Sort ?

4. How helpful is this interactive animation for you to understand the Selection Sort ?

5. How helpful is this interactive animation for you to understand the Bubble Sort?

6. How helpful is the first simulation in the evaluation for you to solve the Counting Sort problem ?

7. How helpful is the second simulation in the evaluation for you to solve the Bubble Sort problem ?

8. Does this animation overal help you to understand the materials ?
2. Determine scale level of ease of use application of interactive animations.

3. How helpful is this interactive animation for you to understand the Sequencial search ?

4. How helpful is this interactive animation for you to understand the Binary search ?

5. How helpful is the first simulation in the evaluation for you to solve the Sequencial search problem?

6. How helpful is the second simulation in the evaluation for you to solve the Binary Search problem ?

7. Does this animation overal help you to understand the materials ?

For the question number 1, every students has taken the Algorithm and programming course. And the answer number 2 until the final question can be seen in the graphics.
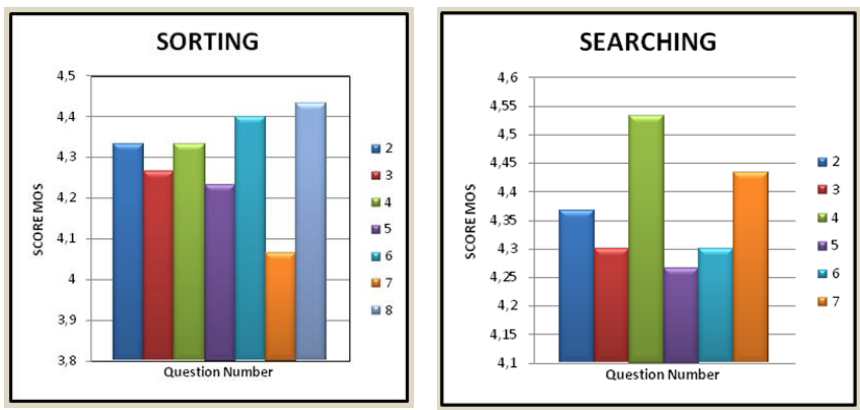

Fig. 4. The results of questionnaires on Sorting and Searching chapter

The result of pre-test post-test is given by the table 1 . The average pre-test and post test value are increasing significantly after the students learned the material with Flash animation.

TABLE I. The AVERAge VAlues of Pretest AND Posttest

\begin{tabular}{|l|l|l|}
\hline Chapter & Average Pretest Value & Average Posttest Value \\
\hline Sorting & 37,5 & 94,17 \\
\hline Searching & 61,67 & 96,67 \\
\hline
\end{tabular}

\section{CONCLUSION}

Based on the responses of students that is tested in this study, we concluded that interactive media can help students in understanding the material being studied. Barriers in understanding the material can be solved by making analogies or visualizations of related material in the animation form.

\section{ACKNOWLEDGMENT}

Research on the use of learning aids in the form of interactive media is still the early step as an effort to improve the learning outcomes. Therefore, it is recommended so that this study is continued to be developed in the other subjects. 


\section{REFERENCES}

[1] Borg W R and Gall M D. 4th Educational Research: An Introduction (New York: Longman Inc); 1989

[2] Rossa A and Shalahuddin. Modul Pembelajaran : Algoritma dan Pemrograman. Modula Bandung.

[3] Hudiono B. Pengembangan dan implementasi bahan ajar interaktif berbasis TIK menggunakan program slide show powerpoint by using audio effect bagi guru matematika SMP di pedalaman kubu Kalimantan Barat. Laporan Penelitian Strategis Nasional, Pontianak : Universitas Tanjungpura (Tidak dipublikasikan); 2013

[4] Hudiono, B. Model peningkatan profesionalisme melalui pengembangan pembelajaran matematika berbasis teknologi informasi dan komunikasi di kalangan guru perkotaan dan luar kota di Wilayah Kalimantan Barat. Laporan Penelitian Fundamental, Pontianak : Universitas Tanjungpura (Tidak dipublikasikan); 2013
[5] Nurtantio P. Kreasikan Animasi-mu dengan Adobe Flash dalam Membuat Sistem Multimedia Interaktif (Yogyakarta: Andi Offset); 2013

[6] Riyanto Y. Paradigma Baru Pembelajaran (Surabaya: Kencana Media Group); 2012

[7] Setyosari P. Metode Penelitian Pendidikan dan Pengembangan (Jakarta: Kencana); 2012

[8] Sukardi. Metodologi Penelitian Pendidikan : Kompetensi dan Praktiknya (Jakarta: Bumi Aksara); 2003

[9] Tim Puslitjaknov. Metode Penelitian Pengembangan Pusat Penelitian Kebijakan dan Inovasi Pendidikan Badan Penelitian dan Pengembangan Departemen Pendidikan Nasional; 2008

[10] Trianto. Mendesain Pembelajaran Inovatif-Progresif (Jakarta: Kencana); 2010 